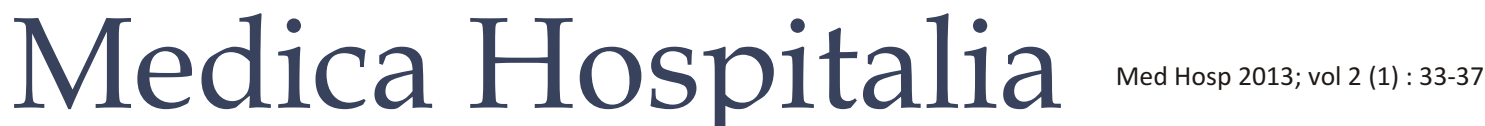

Original Article

\section{Korelasi Antara Berat Badan Ibu Hamil dengan Berat Lahir Bayi}

\author{
Charles Budiman*, Besari Adi Pramono**, Julian Dewantiningrum** \\ *Mahasiswa program pendidikan S-1 kedokteran umum Fakultas Kedokteran Universitas Diponegoro Semarang \\ **Staf pengajar Bagian Obstetri dan Ginekologi Fakultas Kedokteran Universitas Diponegoro Semarang
}

\begin{abstract}
Abstrak
Latar belakang: Berat lahir adalah indikator yang penting dan reliabel bagi kelangsungan hidup neonatus dan bayi, baik ditinjau dari segi pertumbuhan fisik dan perkembangan status mentalnya. Berat badan ibu hamil, tinggi ibu hamil dan kenaikan berat badan ibu selama kehamilan mampu memprediksi berat lahir secara signifikan. Namun, terdapat kesulitan pemantauan kenaikan berat badan saat kehamilan dan kurangnya informasi mengenai berat badan sebelum hamil karena buruknya pelayanan kesehatan di negara berkembang. Penelitian ini bertujuan untuk menemukankorelasi antara berat badan ibu hamil dengan berat lahir bayi di Indonesia.

Metode: Desain penelitian adalah observasional analitik dengan pendekatan cross sectional. Data penelitian ini diperoleh dari rekam medik ibu hamil yang melakukan persalinan di RSUP Dr. Kariadi pada Januari-Februari 2011. Dilakukan pencatatan terhadap berat badan ibu hamil, berat lahir bayi, umur ibu, paritas, tinggi badan ibu, dan kadar hemoglobin. Data tersebut dianalisis dengan uji korelasi dan regresi multipel.

Hasil: Seratus lima ibu menunjukkan adanya korelasi positif antara berat badan ibu hamil $(r=0,462 ; p<0,01)$, umur ibu hamil $(r=0,275$; $p<0,01)$, paritas $(r=0,212 ; p<0,05)$, tinggi badan ibu $(r=0,308$; $p<0,05)$ dengan berat lahir bayi. Namun, ditemukan korelasi negatif antara kadar hemoglobin $(r=-0,152 ; p>0,05)$ dengan berat lahir bayi. Analisis regresi multipel menunjukkan bahwa faktor penentu berat lahir dalam penelitian ini adalah berat badan ibu hamil dan umur ibu.

Simpulan: Terdapat korelasi antara berat badan ibu hamil dengan berat lahir bayi.
\end{abstract}

Kata kunci: berat badan ibu hamil, berat lahir bayi, korelasi

\section{Correlation between maternal weight and birth weight}

\begin{abstract}
Background: Birth weight is an important and reliable indicator for neonatal and infant survival, its physical growth and mental development. Maternal weight, height and weight gain during pregnancy have all been shown to be significant predictors of birth weight. However, monitoring gestational weight gain involves considerable difficulties due to poor health services in developing countries. The aim of this study was to examine the correlation between maternal weight and birth weight in Indonesia.

Methods: The study design was observational cross-sectional with analytical approach. The research data was obtained from Dr. Kariadi Hopital's medical records of pregnant mother who having labour on January-February 2011. Recordings were made on maternal weight, birth weight, maternal age, parity, maternal height, and hemoglobin levels. The data were analyzed using correlation and multiple regression test.

Results: One hundred and five women showed positive correlations between maternal weight $(r=0.462, p<0.01)$, maternal age $(r=0.275, p<0.01)$, parity $(r=0.212, p<0.05)$, maternal height $(r=0.308, p<0.01)$ and birth weight. However, negative correlation was found between hemoglobin levels ( $r=-0.152$, $p>0.05$ ) and birth weight. Multiple regression analysis revealed that the determinants of birth weight in this study are maternal weight and maternal age.

Conclusion: There is a correlation between maternal weight and birth weight
\end{abstract}

Keywords: maternal weight, birth weight, correlation

\section{PENDAHULUAN}

Kehamilan merupakan suatu keadaan fisiologisyang menjadi dambaan setiap pasangan suami-istri. Pada masa kehamilan, ibu harus mempersiapkan diri untuk menyambut kelahiran bayinya. Ibu yang sehat dapat melahirkan bayi yang sehat dan sempurna secara jasmaniah dengan berat badan yang cukup. ${ }^{1}$
Berat lahir adalah indikator yang penting dan reliabel bagi kelangsungan hidup neonatus dan bayi, baik ditinjau dari segi pertumbuhan fisik dan perkembangan status mentalnya. Berat lahir juga dapat digunakan sebagai indikator umum untuk mengetahui status kesehatan, gizi dan sosial ekonomi dari negara maju dan negara berkembang. ${ }^{2}$ Dalam hal ini, berat lahir yang tidak seimbang, baik kurang atau berlebih, dapat 
menyebabkan komplikasi bagi ibu dan bayinya.

Bayi berat lahir rendah (BBLR)/ kurang dari $2500 \mathrm{~g}$ menyumbang 42,5\%-56\% kematian perinatal. Risiko kematian BBLR 5-9 kali lebih tinggi dibandingkan dengan bayi dengan berat lahir normal. ${ }^{3}$ Bayi berat lahir rendah juga akan mengalami peningkatan risiko terkena penyakit metabolik ketika dewasa seperti hipertensi dan diabetes melitus tipe $2{ }^{4}$ Berdasarkan sebuah studi di Amerika, ibu hamil yang melahirkan BBLR memiliki risiko terkena penyakit jantung karena mengalami peninggian tekanan darah, lemak, glukosa, insulin, interleukin 6 (IL-6) dan konsentrasi CRP (C-reaktif protein).$^{5}$

Di lain pihak, terdapat risiko komplikasi dari bayi berat lahir berlebih (lebih dari $4000 \mathrm{~g}$ ), baik yang dialami oleh ibu maupun bayi itu sendiri. Resiko komplikasi ibu saat melahirkan antara lain perdarahan, infeksi, sectio caesar, pre-eklampsi, sedangkan risiko yang mengancam bayi sewaktu dilahirkan adalah mengalami distosia dan kematian perinatal. ${ }^{6}$ Beberapa studi juga menyebutkan bahwa bayi yang memiliki berat badan lebih dari $4000 \mathrm{~g}$ juga meningkatkan risiko beberapa penyakit ketika dewasa misalnya kanker payudara pada wanita dan diabetes melitus tipe $2 .^{4}$

Berat badan ibu hamil, tinggi ibu hamil dan kenaikan berat badan ibu selama kehamilan mampu memprediksi berat lahir secara signifikan. ${ }^{7}$ Namun, terdapat kesulitan pemantauan kenaikan berat badan saat kehamilan dan kurangnya informasi mengenai berat badan sebelum hamil karena buruknya pelayanan kesehatan di negara berkembang. ${ }^{8-10}$

\section{METODE}

Pengumpulan data untuk penelitian ini dilakukan dengan menelaah catatan medik ibu-ibu yang melahirkan di RSUP Dr. Kariadi pada bulan Januari 2011 sampai Februari 2011. Desain penelitian ini adalah observasional analitik dengan pendekatan cross sectional.
Subyek penelitian dipilih dengan menggunakan metode consecutive sampling dan memenuhi kriteria inklusi dan eksklusi. Kriteria inklusi yang digunakan adalah ibu yang melahirkan bayi lahir hidup yang berasal dari kehamilan tunggal dan cukup bulan serta jarak kehamilan terakhir 24-60 bulan. Kriteria eksklusi yang digunakan adalah bayi yang memiliki kelainan kongenital atau ibu yang mengalami hidramnion, infeksi TORCH, preeklamsia/eklamsia, dan memiliki penyakit sistemik. Pemantauan kenaikan berat badan saat kehamilan dan berat badan sebelum hamil adalah kelemahan dari penelitian ini.

Data yang terkumpul dilakukan cleaning, coding dan tabulasi ke dalam komputer, kemudian dilanjutkan dengan analisis data dengan menggunakan program SPSS 12 untuk dilakukan uji korelasi. Jika sebaran data normal $(p>0,05)$, maka dipilih uji Pearson (parametrik), sedangkan jika sebaran data tidak normal $(p<0,05)$, maka diupayakan untuk melakukan transformasi data menjadi normal dan dilakukan uji parametrik. Namun, jika transformasi data tidak menghasilkan sebaran data yang normal, maka dipilih uji Spearman (non parametrik) sebagai alternatif uji Pearson. Penelitian ini telah mendapatkan ijin dari Komite Etik penelitian FK UNDIP/RSUP Dr. Kariadisemarang.

\section{HASIL}

Tercatat ada $208 \mathrm{ibu}$ hamil yang melakukan persalinan di kamar bersalin RSUP Dr. Kariadi Semarang pada periode 1 Januari 2011 - 28 Februari 2011, namun hanya 105 pasien yang memenuhi kriteria inklusi dan eksklusi.

Hasil dari penelitian ini didapatkan korelasi antara berat badan ibu hamil dengan berat lahir bayi. Dengan uji statistik, didapatkan hasil berupa arah korelasi positif dan kekuatan korelasi sedang $(r=0,463)$ dengan $p<0,01$ (Gambar 1). Selain itu juga didapatkan korelasi positif antara tinggi badan ibu dengan berat lahir bayi $(r=0,308)$ dengan $p<0,01$ (Gambar 2$)$.

TABEL 1

Karakteristik seluruh subyek penelitian

\section{Variabel}

Berat badan ibu hamil $(\mathrm{kg})$

Berat lahir bayi (gram)

Umur ibu (tahun)

Paritas

Tinggi badan ibu $(\mathrm{cm})$

Kadar hemoglobin (gr\%)
Rerata (SB)

$-$

$2988,57(416,516)$

$-$

$-$

$-$

$11,3(1,5)$
Median (min-maks)

$59(42-135)$

$26(17-43)$

$0(0-4)$

$154(143-168)$ 


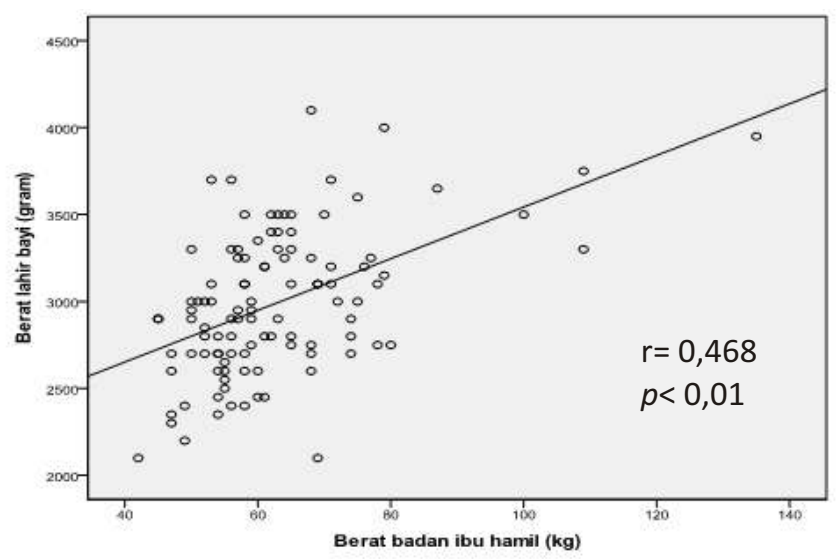

Gambar 1. Korelasi antara berat badan ibu hamil dengan berat lahir bayi.

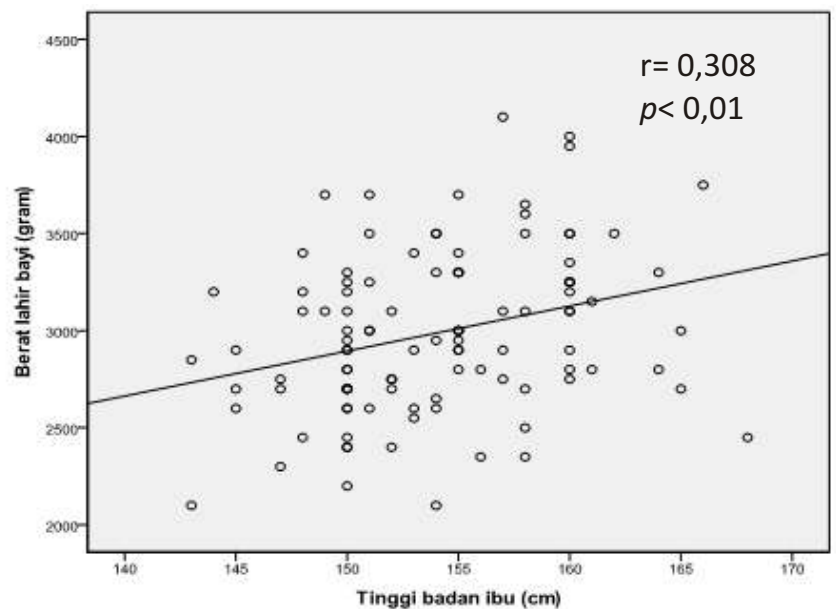

Gambar 2. Korelasi antara tinggi badan ibu dengan berat lahir bayi

Pada uji korelasi antara umur ibu hamil dengan berat lahir bayi, didapatkan hasil berupa arah korelasi positif dan kekuatan korelasi lemah $(r=0,275)$ dengan $p<0,01$ (gambar 3) dan paritas ibu dengan berat lahir bayi didapatkan hasil berupa arah korelasi positif dan kekuatan korelasi lemah $(r=0,212)$ dengan $p<0,05$ (gambar 4).

Hasil uji korelasi antara kadar hemoglobin dengan berat lahir bayi didapatkan korelasi negatif dan kekuatan korelasi sangat lemah $(r=-0,152)$ dengan $p>0,05$.

Berat lahir bayi ditentukan oleh berat badan ibu hamil, umur ibu, paritas ibu, tinggi badan ibu dan kadar hemoglobin. Uji regresi multipel diperlukan untuk mengetahui variabel yang paling berpengaruh terhadap berat lahir bayi. Setelah diuji dengan cara ini, ternyata variabel penentu berat lahir bayi (y) adalah berat badan ibu hamil (x1) dan umur ibu (x2). Hasil akhir didapatkan suatu persamaan regresi linier yaitu: $y=1735,42+14,07$ $x 1+13,95 \times 2$.

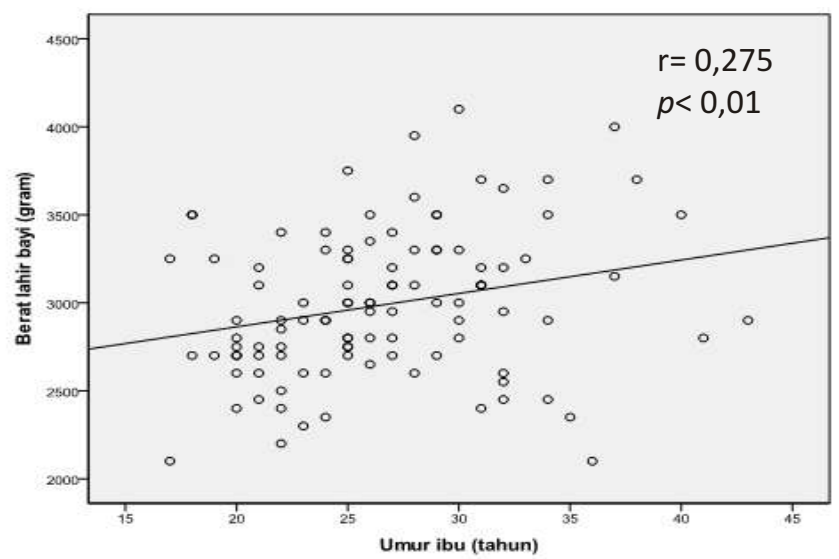

Gambar 3. Korelasi antara umur ibu hamil dengan berat lahir bayi.

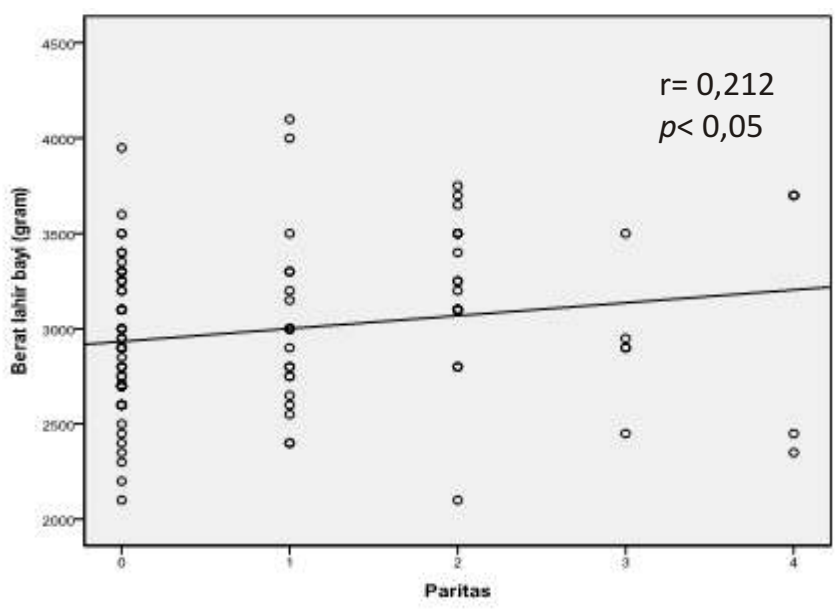

Gambar 4. Korelasi antara jumlah paritas ibu dengan berat lahir bayi

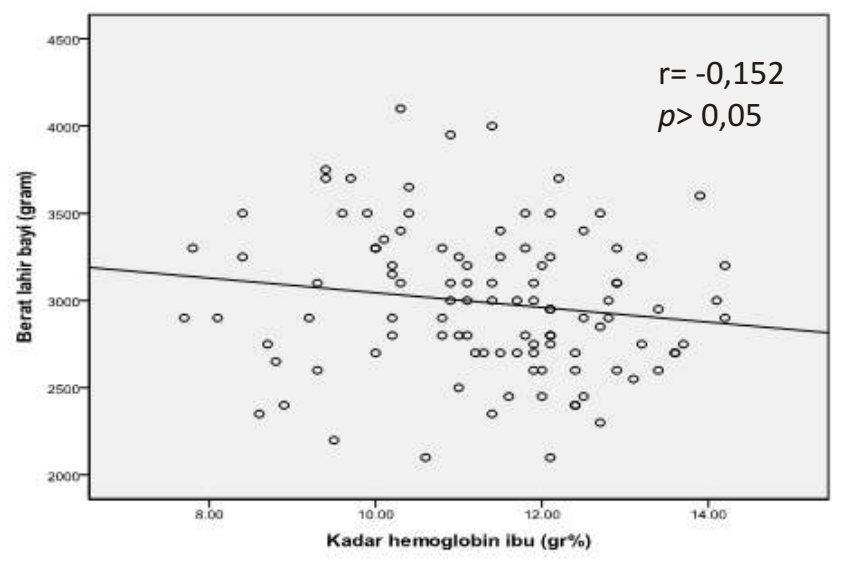

Gambar 5. Korelasi antara kadar hemoglobin dengan berat lahir bayi. 


\begin{tabular}{|c|c|c|}
\hline \multicolumn{3}{|c|}{$\begin{array}{l}\text { Variabel yang menentukan berat lahir bayi } \\
\text { dengan regresi multipel }\end{array}$} \\
\hline Variabel & p & IK 95\% \\
\hline Berat badan ibu hamil & 0,000 & 8,999-19,137 \\
\hline Umur ibu & 0,033 & $1,181-26,786$ \\
\hline
\end{tabular}

Adj. $R^{2}(\%)=26,3 \%, p<0,000$

\section{PEMBAHASAN}

Pada penelitian ini, didapatkan bahwa makin berat badan ibu hamil, makin bertambah juga berat bayi lahir bayi. Hal ini ditunjukkan dengan hasil uji statistik dengan tingkat kemaknaan sebesar $p<0,01$ dengan kekuatan korelasi sedang. Berat badan ibu hamil merupakan komponen hasil penjumlahan berat badan ibu sebelum hamil dan kenaikan berat badan selama kehamilan. Jika ditinjau berdasarkan komponennya, maka hasil penelitian ini memiliki kemiripan dengan beberapa penelitian. Berat badan ibu sebelum hamil yang merupakan gambaran status gizi ibu, memiliki hubungan erat dengan berat lahir bayi, dimana ibu yang kurus atau malnutrisi melahirkan bayi berat lahir rendah dan ibu yang obesitas melahirkan bayi makrosomia. Hal tersebut disebutkan dalam penelitian yang dilakukan oleh Phaneendra dkk. ${ }^{2}$ Kenaikan berat badan selama kehamilan merupakan gambaran laju pertumbuhan janin dalam kandungan yang perlu diperhatikan karena kenaikan berat badan yang kurang maupun berlebih bisa menimbulkan permasalahan yang serius bagi bayi dan ibunya, seperti penelitian yang dilakukan oleh Nur AH. ${ }^{9}$

Pada penelitian ini, didapatkan bahwa makin tua umur ibu hamil, makin bertambah juga berat bayi yang dilahirkan. Hal ini menunjukkan umur ibu secara bermakna sebagau penentu berat lahir dengan uji statistik $p<0,01$ dengan kekuatan korelasi lemah. Hasil ini sesuai dengan penelitian yang dikemukakan oleh Minoo dkk bahwa kejadian bayi berat lahir rendah lebih banyak terjadi pada ibu-ibu usia muda terutama yang berumur kurang dari 20 tahun karena status psikologisnya yang belum matang khususnya dalam pengambilan keputusan. ${ }^{10}$

Bila ditinjau dari paritas, didapatkan secara bermakna bahwa makin tinggi paritas, makin tinggi berat lahir bayi. Hal ini ditunjukkan dengan hasil uji statistik dengan tingkat kemaknaan sebesar $p<0,05$ dengan kekuatan korelasi lemah. Hasil ini sesuai dengan penelitian yang dilaporkan oleh Prakesh SS bahwa nulipara memiliki resiko lebih besar melahirkan bayi berat lahir rendah dibanding multipara karena mungkin dipengaruhi oleh beberapa faktor seperti kondisi kesehatan, status nutrisi, kebiasaan merokok, berat badan yang kurang sebelum hamil, rendahnya kenaikan berat badan selama kehamilan dan kurangnya asuhan antenatal, hipertensi gravidarum dan kelainan vaskularisasi plasenta. ${ }^{11}$

Hasil penelitian menunjukkan bahwa makin tinggi badan ibu hamil maka makin besar juga berat bayi yang dilahirkan. Hal ini ditunjukkan dengan tingkat kemaknaan sebesar $p<0,01$ dengan kekuatan korelasi lemah. Hasil ini sesuai dengan penelitian sebelumnya yang dilakukan Kate dkk bahwa ibu yang memiliki postur pendek memiliki risiko melahirkan bayi dengan berat lahir lebih rendah karena diperkirakan postur pendek mencerminkan keadaan status gizi yang kurang baik di masa lampau. ${ }^{12}$

Pada penelitian ini, didapatkan bahwa makin rendah kadar hemoglobin ibu hamil, maka makin tinggi berat lahir bayi, tetapi korelasi ini tidak bermakna dengan uji statistik sebesar $p>0,05$ dan kekuatan korelasinya sangat lemah. Hasil ini sama seperti hasil penelitian Destuty H yang melaporkan bahwa tidak ada hubungan antara kadar hemoglobin ibu hamil dengan berat lahir bayi karena berat lahir tidak hanya ditentukan oleh kadar hemoglobin saja, tetapi juga dipengaruhi oleh berbagai faktor seperti umur ibu, jarak kelahiran, paritas, status gizi ibu hamil, pemeriksaan kehamilan, dan penyakit pada saat kehamilan. ${ }^{13}$ Hasil penelitian tidak bermakna ini dimungkinkan karena dari data penelitian didapatkan bahwa sebagian besar ibu yang memiliki kadar hemoglobin rendah melahirkan bayi berat lahir normal. Hal ini disebabkan karena berat lahir tidak mutlak ditentukan oleh kadar hemoglobin saja seperti yang dinyatakan Philip JS. ${ }^{14}$

Penentu berat lahir bayi pada penelitian ini dengan menggunakan uji statistik regresi multipel secara berturut-turut adalah berat badan ibu hamil dan unur ibu. Penelitian yang dilakukan Phaneendra dkk menyatakan bahwa secara berturut-turut tinggi badan ibu, periode gestasi dan kenaikan berat badan selama kehamilan sebagai penentu berat badan bayi yang dilahirkan. $^{2}$

\section{SIMPULAN}

Dari hasil penelitian ini dapat disimpulkan bahwa terdapat korelasi antara berat badan ibu hamil dengan berat lahir bayi.

Dalam pengelolaan kehamilan, sebaiknya lebih diperhatikan ibu-ibu yang berusia kurang dari 20 tahun, baru pertama kali melahirkan, dan kurus serta memiliki kenaikan berat selama kehamilan yang kecil karena lebih berisiko melahirkan bayi berat lahir rendah. 


\section{DAFTAR PUSTAKA}

1. Susiana IWS. Hubungan Antara Kenaikan Berat Badan, Lingkar Lengan Atas dan Kadar Hemoglobin Ibu Hamil Trisemester III dengan Berat Bayi Lahir di Puskesmas Ampel I Boyolali Tahun 2005 [skripsi]. Semarang: FKM Unnes. 2005.

2. Phaneendra RRS, Prakash KP, Sreekumaran NN. Influence of Pre-Pregnancy Weight, Maternal Height and Weight Gain During Pregnancy on Birth Weight. Bahrain Med Bull. 2001;23(1):22-6.

3. Sugeng S, Hamam H. Pengaruh Anemia Selama Masa Kehamilan Terhadap Kejadian Berat Badan Lahir Rendah (BBLR) Dan Prematuritas. Sains Kesehatan. 2001;14(1):69-79.

4. Line R, Hanne KH, Hanne K, Lars FM, Ann T, Bent O. Association Between Maternal Weight Gain and Birth Weight. ACOG. 2007;109(6):1309-15.

5. Janet MC, Anne BN, James NR, Kim CS, Sheryl FK, Tamara H, Rebbeca J, Lisa HC, Suzzane S, Hilsa NA, Roberta BN. Association Between Infant Birth Weight and Maternal Cardiovascular Risk Factors in the Health, Aging, and Body Composition Study. Ann Epidemiol. 2007;17(1):36-43.

6. Conrad K, Martha MW. Prepregnant Body Mass Index, Weight Gain and The Risk of Delivering Large Babies Among NonDiabetic Mothers. Int J Gynaecol Obstet. 2007;97(2):100-4.

7. Jananthan R, Wijesinghe DGNG, Sivananthawerl T. Maternal Anthropometry as a Predictor of Birth Weight. SLJOG. 2009;21(1):89-98.
8. Mortazavi F, Khadiv ZT. The Relationship between Maternal Anthropometric Measurement and Birth Weight. APJCN. 2004;13(3):154-0.

9. Nur AH. Hubungan Pertambahan Berat Badan Ibu Saat Hamil dengan Berat Bayi Lahir di Praktik Bidan Sumiariani, AMKeb Kecamatan Medan Johor [skripsi]. Medan: FK USU. 2010.

10. Minoo R, Sareh A, Fariba M, Mitra AS. The Effect of Maternal Age on Pregnancy Outcome. Asian J. Med. Sci. 2010;2(3):159-62.

11. Prakesh SS. Parity and low birth weight and preterm birth: a systematic review andmeta-analyses. Acta Obstet Gynecol Scand. 2010;89:862-75.

12. Kate EP, Barbara A, Steve S. Maternal height, pregnancy weight gain, and birthweight. Am. J. Hum. Biol. 2000;12(5):682-7.

13. Destuty H. Hubungan Kadar Hemoglobin Ibu Hamil dengan Berat Badan Bayi Baru Lahir di RSUP Haji Adam Malik Medan [skripsi]. Medan: FK USU. 2010.

14. Philip JS. Maternal hemoglobin concentration and birth weight. Am. J. Clin. Nutr. 2000;71(5):1285-7. 